\title{
Final Report for DOE Award DE-FC02-07ER64340
}

\section{PI: Peter Gent, NCAR}

\section{Executive Summary}

The objective of this award was to build a scalable and extensible Earth System Model that can be used to study climate change science. That objective has been achieved with the public release of the Community Earth System Model, version 1 (CESM1). In particular, the development of the CESM1 atmospheric chemistry component was substantially funded by this award, as was the development of the significantly improved coupler component. The CESM1 allows new climate change science in areas such as future air quality in very large cities, the effects of recovery of the southern hemisphere ozone hole, and effects of runoff from ice melt in the Greenland and Antarctic ice sheets. Results from a whole series of future climate projections using the CESM1 are also freely available via the web from the CMIP5 archive at the Lawrence Livermore National Laboratory. Many research papers using these results have now been published, and will form part of the $5^{\text {th }}$ Assessment Report of the United Nations Intergovernmental Panel on Climate Change, which is to be published late in 2013.

\section{Accomplishments and Project Activities}

The abstract of the proposal for this award states, "Our challenge for SciDAC is to transform an existing, state-of-the-science third generation global climate model, the Community Climate System Model (CCSM), to create a first generation Earth system model that fully simulates the coupling between the physical, chemical, and biogeochemical processes in the climate system. The model will incorporate new processes necessary to predict future climates based on the specification of greenhouse gas emissions rather than specification of atmospheric concentrations, as is done in present models that make assumptions about the carbon cycle that are likely not valid. We will include comprehensive treatments of the processes governing well-mixed greenhouse gases, natural and anthropogenic aerosols, the aerosol indirect effect and tropospheric ozone for climate change studies. We will improve the representation of carbon and chemical processes.” All of these goals have been accomplished in that the CESM1 has been used to study many new scientific problems that could not be studied using the CCSM4. In particular, the most recent version of the atmosphere component, CAM5, includes new prognostic equations for aerosols and the formation of clouds now depends on the quantity and size of these aerosols. Therefore, the indirect effect of aerosols is included in coupled climate runs using the CAM5. CAM5 also includes the latest versions of both the full chemistry component and the fast chemistry component. The CESM1 has biogeochemistry modules in both the ocean and land components, and the atmosphere component advects the biogeochemistry tracers around. The CESM1 has been run over the $20^{\text {th }}$ Century when greenhouse gas emissions have been specified, and 
the atmosphere concentration of greenhouse gases is then predicted, rather than specified. However, funding from this award has only been used to develop the new atmosphere chemistry component, and not to develop the CAM5 or the biogeochemistry modules.

In addition, the proposal abstract states, “These additions are not possible unless we also improve the software and testing framework of the CCSM to enable the rapid integration and evaluation of new components. To focus these efforts, specific integration tasks are proposed: inclusion of a new ice sheet model, more flexible horizontal and vertical grids and advanced dynamical formulations. Integration and evaluation work will rely on collaboration with other SciDAC Centers for Enabling Technologies and Scientific Application Partnerships." Funding from this award has been used to support members of the CESM Software Engineering Group, with the following accomplishments. An important part of the CCSM4 and CESM1 model releases has been the new coupler infrastructure, CPL7. It consists of a single executable design that provides flexibility in running the CESM components sequentially, concurrently, or in a mixed sequentialconcurrent mode. This flexibility is achieved through the introduction of a top-level driver that runs on every computer processor and controls the time sequencing, processor concurrency, and exchange of state information and fluxes between components. In CPL7, all model components and the coupler itself can run on potentially overlapping processor subsets. This design permits the model system to have greatly increased flexibility to achieve the model component layout that optimizes the overall performance and efficiency of the model. The CCSM4 and CESM1 also include a new scripting system that permits the user to easily specify the processor layout of the model components, and is also accompanied by informative timing utilities. Together, these tools enable a user to create a wide variety of 'out of the box' experiments for different model configurations and resolutions, and also to determine the optimal load balance for those experiments to ensure maximum throughput and efficiency on a wide variety of DOE and NSF supercomputers. The new CPL7 infrastructure is a significant advance on the old CCSM3 coupler, where all components were constrained to run as separate executables on unique processor sets, and there was no concept of a top-level driver.

A new ice sheet component has also been released as part of the CESM1, but it's development has not been funded by this DOE award. However, control and $20^{\text {th }}$ Century runs of the CESM1 have been completed where the Greenland ice sheet is interactively coupled into the predicted simulation. Thus, as the atmosphere warms, ice in Greenland starts to melt and the melt enters the ocean around Greenland by means of the river routing scheme in the model. This is one of the first occasions where an interactive ice sheet model has been run as part of a fully interactive, quite high resolution climate model. The ice sheet model development has been overseen by the Land Ice Working Group, which was a new addition to the CESM working groups about three years ago.

In summary, all of the goals outlined in the proposal for this award have been achieved. However, this award has partially funded only the new atmosphere chemistry and coupler components, and not the other new component developments that were an integral part of the development of the CCSM into a full Earth System Model, the CESM. 


\section{PUBLICATIONS of Jean-Francois Lamarque and Andrew Conley}

Lamarque, J.-F., T. C. Bond, V. Eyring, C. Granier, A. Heil, Z. Klimont, D. Lee, C. Liousse, A. Mieville, B. Owen, M. G. Schultz, D. Shindell, S. J. Smith, E. Stehfest, J. Van Aardenne, O. R. Cooper, M. Kainuma, N. Mahowald, J. R. McConnell, V. Naik, K. Riahi and D. P. van Vuuren: Historical (1850-2000) gridded anthropogenic and biomass burning emissions of reactive gases and aerosols: methodology and application. Atmos. Chem. Phys., 10, doi:10.5194/acp-10-7017-2010, 7017-7039, 2010.

Lamarque, J.-F., G. P. Kyle, M. Meinshausen. K. Riahi, S. J. Smith, D. P. van Vuuren, A. Conley, F. Vitt: Global and regional evolution of short-lived radiatively-active gases and aerosols in the Representative Concentration Pathways. Climatic Change, doi:10.1007/s10584-011-0155-0, 2011.

Lamarque, J.-F, L. K. Emmons, P. G. Hess, D. E. Kinnison, S. Tilmes, F. Vitt, C. L. Heald, E. A. Holland, P. H. Lauritzen, J. Neu, J. J. Orlando, P. Rasch, G. Tyndall: CAM-chem: description and evaluation of interactive atmospheric chemistry in CESM. Geosci. Mod. Dev., 5, 369-411, doi:10.5194/gmd-5-369-2012, 2012.

Meehl, G., W. Washington, J. Arblaster, A. Hu, H. Teng, C. Tebaldi, J.-F. Lamarque, A. Conley, W. Strand, J. White; Climate system response to external forcings and climate change projections in CCSM4. J. Climate, 25, 3661-3683, 2012.

Cionni, I., V. Eyring, J.-F. Lamarque, W. J. Randel, D. S. Stevenson, F. Wu, G. E. Bodeker, T. G. Shepherd, D. T. Shindell, and D. W. Waugh: Ozone database in support of CMIP5 simulations: results and corresponding radiative forcing. Atmos. Chem. Phys, 11, 11267-11292, doi:10.5194/acp-11-11267-2011, 2011.

Conley, A., J.-F. Lamarque, F. Vitt, W. D. Collins and J. T .Kiehl: PORT, a CESM tool for the diagnosis of radiative forcing, Geosci. Model Dev. Discuss., 5, 2687-2704, 2012.

Bowman, K. W., D. T. Shindell, J.-F. Lamarque, P. J. Young, , M de la Torre, H. Worden, D. Bergmann, D. Stevenson, P. Cameron-Smith, W. J. Collins, R. Doherty, S. Dalsoren, V. Eyring, G. Faluvegi, , G. Folberth, S. J. Ghan, L. W. Horowitz, B. Josse, Y. Lee, I. McKenzie, T. Nagashima, V. Naik, D. Plummer, S. Rumbold, R. Skeie, D. S. Stevenson, S. Strode, K. Sudo, S. Szopa, A.Voulgarakis and G. Zeng, A. Aghedo: Observational Constraints on radiative forcing from the Atmospheric Chemistry Climate Model Intercomparison Project (ACCMIP). Atmos. Chem. Phys. Disc., 2012.

Shindell, D. T., J.-F. Lamarque, M. Schulz, M. Flanner, C. Jiao, M. Chin, P. J. Young, Y. Lee, G. Milly, G. Faluvegi, Y. Balkanski, W. J. Collins, A. J. Conley, S. Dalsoren, R. Easter, S. J. Ghan, L. Horowitz, X. Liu, G. Myhre, T. Nagashima, V. Naik, L. Rotstayn, S. Rumbold, R. Skeie, K. Sudo, S. Szopa, T. Takemura, J.-H. Yoon: Radiative forcing in the ACCMIP historical and future climate simulations, Atmos. Chem. Phys. Disc., 2012. 
Stevenson, D. S., P. J. Young, V. Naik, J.-F. Lamarque, D. T. Shindell, R. Skeie, S. Dalsoren, G. Myhre, T. Berntsen, G. Folberth, S. Rumbold, W. J. Collins, I. A. MacKenzie, R. M. Doherty, G. Zeng, T. van Noije, A. Strunk, D. Bergmann, P. Cameron-Smith, D. Plummer, S. A. Strode, L. Horowitz, Y. Lee, S. Szopa, K. Sudo, T. Nagashima, B. Josse, I. Cionni, M. Righi, V. Eyring, O. Wild, K. W. Bowman: Tropospheric ozone changes and radiative forcing 1850-2100 in the Atmospheric Chemistry and Climate Model Inter-comparison Project (ACCMIP). Atmos. Chem. Phys. Disc., 2012.

\section{PUBLICATIONS of Mariana Vertenstein and Anthony Craig}

Anthony P. Craig, Mariana Vertenstein, and Robert Jacob: A new flexible coupler for earth system modeling developed for CCSM4 and CESM1, 2012: International Journal of High Performance Computing Applications February 2012, 26: 31-42, doi:10.1177/1094342011428141.

John M. Dennis, Mariana Vertenstein, Patrick H. Worley, Arthur A. Mirin, Anthony P. Craig, Robert Jacob, and Sheri Mickelson, 2012: Computational performance of ultrahigh-resolution capability in the Community Earth System Model. International Journal of High Performance Computing Applications February 2012, 26: 5-16, doi:10.1177/1094342012436965.

John M. Dennis, Jim Edwards, Ray Loy, Robert Jacob, Arthur A. Mirin, Anthony P. Craig, and Mariana Vertenstein, 2012: An application-level parallel I/O library for Earth system models. International Journal of High Performance Computing Applications February 2012, 26: 43-53, doi:10.1177/1094342011428143.

Katherine J. Evans, Andrew G. Salinger, Patrick H. Worley, Stephen F. Price, William H. Lipscomb, Jeffrey A. Nichols, James B. White III, Mauro Perego, Mariana Vertenstein, James Edwards, and Jean-François Lemieux, 2012: A modern solver interface to manage solution algorithms in the Community Earth System Model. International Journal of High Performance Computing Applications February 2012, 26: 54-62, doi:10.1177/1094342011435159.

\section{PUBLICATIONS of Peter Gent}

Gent, P. R., S. G. Yeager, R. B. Neale, S. Levis, and D. A. Bailey, 2010: Improvements in a half degree atmosphere/land version of the CCSM. Climate Dynamics, 34, 819-833, doi:10.1007/s00382-009-0614-8.

Gent P. R., G. Danabasoglu, L. Donner, M. Holland, E. Hunke, S. Jayne, D. Lawrence, R. Neale, P. Rasch, M. Vertenstein, P. Worley, Z-L. Yang, and M. Zhang, 2011: The Community Climate System Model version 4. J. Climate, 24, 4973-4991.

Bitz, C. M., K. M. Shell, P. R. Gent, D. Bailey, G. Danabasoglu, K. C. Armour, M. M. Holland, and J. T. Kiehl, 2012: Climate sensitivity of the Community Climate System Model version 4. J. Climate, 25, 3053-3070. 


\section{Web sites associated with this award}

Community Earth System Model

http://www.cesm.ucar.edu/

CESM Chemistry Climate Working Group

http://www.cesm.ucar.edu/working groups/Chemistry/

CESM 1.1 Notable Improvements

http://www.cesm.ucar.edu/models/cesm1.1/notable improvements.html

CESM 1.1 User's Guide

http://www.cesm.ucar.edu/models/cesm1.1/cesm/doc/usersguide/book1.html

CAM 5.2 User's Guide (includes atmosphere chemistry model)

http://www.cesm.ucar.edu/models/cesm1.1/cam/docs/ug5 2/ug.html

CPL7 User's Guide (coupler component)

http://www.cesm.ucar.edu/models/cesm1.1/cpl7/doc/book1.html

CESM1.0 Tutorial

www.cesm.ucar.edu/models/cesm1.0/cesm/cesm1 tutorial.pdf

Output from many CCSM4 runs submitted to CMIP5 comparison

http://www.earthsystemgrid.org/dataset/ucar.cgd.ccsm4.cmip5.output.htm

Special Collection of papers on CCSM4 and CESM1 in the Journal of Climate http://journals.ametsoc.org/page/CCSM4/CESM1

Special issue of the International Journal of High Performance Computing Applications on Climate Simulation and Modeling Scalable Computing with the Community Earth System Model

http://hpc.sagepub.com/content/26/1.tc 